\title{
Double Standard Indonesia Dalam Diplomasi Kemanusiaan
}

\begin{abstract}
M. Syaprin Zahidi ${ }^{1}$
Abstrak

Aspek Hukum Humaniter dan Diplomasi Kemanusiaan jika dilihat dari perspektif Indonesia sebenarnya dapat dipertanyakan. Hal ini disebabkan oleh adanya double standard yang ditetapkan oleh Indonesia dalam penanganan masalah Kemanusiaan sehingga Indonesia sama saja dengan Amerika Serikat dalam konteks ini. Hal ini diperkuat dengan data-data mengenai Pembantaian massal yang terjadi pada tahun 1965, pelanggaran-pelanggaran Kemanusiaan di Timor-Timur, Tanjung Priok, Papua, Aceh lalu terbunuhnya beberapa mahasiswa pada era reformasi di Indonesia pada tahun 1998 merupakan pelanggaran berat terhadap kemanusiaan yang sampai saat ini belum tuntas diselesaikan. Pada sisi yang lain Juru bicara Presiden Teuku Faizasyah malah mengklaim bahwa Diplomasi Kemanusiaan menjadi jargon dari kebijakan luar negeri Indonesia.
\end{abstract}

Kata-Kata Kunci : Diplomasi Kemanusiaan, Hukum Humaniter, Pelanggaran Terhadap Kemanusiaan

\begin{abstract}
Humanitaran law and humanitarian diplomacy from Indonesia prespective could be questioned. Why? Because in my opinion Indonesia like a janus person, it same with America in this position with double standard. What that I said it couldbe subjective but if we look a data about collision of human right in Indonesia it could be the answer from my opinion before. It's began from 1965 with genocide, The Collision of Human Rights in East Timor, Tanjung Priok, Papua and Aceh, the abbattoir of students in reformation process 1998 all of that problems it can't be finished all until now. But it couldbe a joke in my opinion when Indonesian president Spokeperson, Teuku Faizasyah, claimed that humanitarian diplomacy is 'flagship' for Indonesian foreign policy (Minutes of Meeting at the Department of International Relations UGM March 2012). So, in this paper i will focus to analyze the janus attitude of Indonesia in it's humanitarian diplomacy.
\end{abstract}

Keywords : Humanitarian Diplomacy, Humanitarian Law, The Collision of Humanitarian Aspects

\section{Pendahuluan}

Terpilihnya Indonesia sebagai anggota Dewan Hak Asasi Manusia (HAM) PBB periode 2011-2014 menunjukkan kepercayaan masyarakat internasional kepada Indonesia sebagai negara yang mampu menyelesaikan permasalahan kemanusiaan baik didalam negerinya maupun di negara lain. Namun, kepercayaan yang diberikan oleh masyarakat
Internasional ini menurut penulis perlu juga untuk dipertanyakan karena dalam realitasnya Indonesia sampai dengan saat ini (2014) masih menyisakan banyak permasalahan kemanusiaan yang belum terselesaikan (Kontras, 2013). Diplomasi Indonesia berkaitan dengan kemanusiaan bisa dikatakan sukses karena akhirnya Indonesia terpilih sebagai anggota Dewan HAM PBB. Namun 
disisi lain, keberhasilan ini dalam bahasa penulis menunjukkan perilaku "janus" dari Indonesia berkaitan dengan permasalahan Kemanusiaan karena didunia internasional Indonesia terlibat aktif dalam penanganan masalah Kemanusiaan namun penanganan masalah Kemanusiaan didalam negeri sendiri terbengkalai.

Aktivitas Indonesia dalam diplomasi Kemanusiaan sebagaimana dijabarkan oleh juru bicara Presiden Susilo Bambang Yudhoyono (SBY) yaitu Teuku Faizasyah dalam suatu diskusi di Departemen Hubungan Internasional, UGM. Terdiri dari tiga hal. Pertama, pengiriman pasukan perdamaian. Kedua, Resolusi Konflik dan Ketiga penanganan bencana. Keikutsertaan Indonesia dalam penanganan masalah kemanusiaan sebagaimana tersebut dalam tiga bentuk aktivitas tersebut sudah sangat menjelaskan ketimpangan atau ketidakseimbangan dalam konteks penanganan masalah Kemanusiaan oleh Indonesia. Hal ini disampaikan Juru Bicara Presiden mengenai aktivitas Indonesia dalam Diplomasi HAM pada diskusi terbatas di Departemen Hubungan Internasional, UGM tahun 2012.

Ketimpangan dalam konteks penanganan masalah Kemanusiaan ini maksudnya adalah terjadi perbedaan kebijakan di luar negeri dan didalam negeri dalam penanganan masalah Kemanusiaan. Kebijakan keluar dari Indonesia terlihat sangat aktif dalam penanganan masalah Kemanusiaan antara lain terlihat dari pengiriman pasukan perdamaian yang dilakukan oleh Indonesia ke Republik Demokratik Kongo, Liberia, Sudan, Lebanon dan beberapa negara lainnya. tapi hal yang berbeda terjadi dalam kebijakan Indonesia ke dalam, banyak permasalahan Kemanusiaan yang hingga saat inipun belum tuntas untuk diselesaikan contohnya adalah permasalahan kematian Aktivis HAM Munir walaupun terdakwanya telah ditetapkan namun masih banyak yang ragu dengan keputusan pengadilan tersebut, Kematian Mahasiswa Trisakti pada tahun 1998 dalam upaya reformasi di Indonesia, penghilangan paksa beberapa aktivis yang sampai saat inipun belum diketahui keberadaannya dan masih banyak lagi sebenarnya.

Secara umum akan ada tiga hal yang penulis soroti dalam konteks pelanggaran dalam aspek kemanusiaan di Indonesia antara lain adalah kebebasan beragama, aspek reformasi peradilan militer yang tidak komprehensif dan kekerasan terhadap perempuan dalam tulisan ini penulis memfokuskan di Papua. ketiga hal tersebut menurut penulis menjadi penting karena menjadi isu utama dalam pelanggaran aspek kemanusiaan di Indonesia. Pembahasan dalam tulisan ini akan penulis bagi menjadi dua bagian. Pertama, penulis akan menyoroti

\footnotetext{
2 Janus yang penulis maksud disini adalah kebijakan double standard yang diterapkan oleh Indonesia berkaitan dengan isu HAM ini.
} 
mengenai Diplomasi Kemanusiaan yang dilakukan oleh Indonesia. Kedua, Pelanggaran aspek kemanusiaan yang terjadi di Indonesia.

\section{Pembahasan}

Diplomasi Kemanusiaan yang dilakukan oleh Indonesia jika mengacu pada penjabaran dari juru bicara presiden Teuku Faizasyah terdiri dari tiga hal. Pertama, pengiriman pasukan perdamaian. Kedua, Resolusi Konflik dan Ketiga penanganan bencana. Penulis akan membahas satu persatu mengenai aktivitas Diplomasi Kemanusiaan Indonesia tersebut.

\section{Pengiriman Pasukan Perdamaian}

Indonesia pertama kali mengirimkan pasukan perdamaiannya ke Mesir pada tahun 1957 dan dinamakan Kontingen Garuda I atau KONGA I yang kemudian dilanjutkan dengan pengiriman-pengiriman pasukan perdamaian berikutnya antara lain ke Kongo, Vietnam, Timur Tengah, Iran-Irak, Namibia, IrakKuwait, Kamboja, Somalia, BosniaHerzegovina, Georgia, Mozambik, Filipina, Tajikistan, Sierra Leone, Liberia, Sudan, Lebanon dan Nepal (Kompas, 2013).

Pengiriman-pengiriman pasukan perdamaian oleh Indonesia ini mendapatkan respon yang cukup baik dari masyarakat di negara tempat penempatan pasukan ini dan PBB sebagai institusi yang mengendalikan pengiriman pasukan perdamaian ke berbagai negara. Hal tersebut contohnya terlihat dalam bentuk permintaan $\mathrm{PBB}$ untuk mengirimkan pasukan tambahan dari Indonesia untuk pelaksanaan tugas sebagai satuan Force Headquarter Support Unit (FHQSU) dan INDOForce Protection Company (INDO FP Coy) menyusul keberhasilan penugasan Kontingen Garuda XXIII bersama dengan UNIFIL dalam pemeliharaan perdamaian di Lebanon. PBB sendiri mengapresiasi keberhasilan pasukan perdamaian dari Indonesia dengan mengeluarkan laporan yang mencantumkan Indonesia sebagai negara dengan urutan ke-15 dari 177 negara yang paling banyak mengirimkan pasukan penjaga perdamaian dunia selain Indonesia dalam daftar 15 besar terdapat negara-negara antara lain Bangladesh, Pakistan, India, Nigeria, Etiopia, Jordan, Ghana dan Afrika Selatan (Kompas, 2013).

$$
\text { Upaya peningkatan eksistensi }
$$
Indonesia sebagai pasukan penjaga perdamaian sangat terlihat pada statement yang dikeluarkan oleh Kepala Staf Angkatan Darat (KSAD) Jenderal TNI Pramono Edhie pada saat pengecekan persiapan pasukan perdamaian yang akan dikirim ke Sudan. KSAD mengatakan "Kamu (pasukan) adalah yang pertama, jadi jangan cederai TNI. Jangan sampai kesan bagus dari PBB terhadap kamu hanya kesan pertama" (Detik.Com, 2013). Statement tersebut secara holistik menunjukkan upaya pencitraan yang dilakukan oleh Indonesia dalam konteks Diplomasi Kemanusiaan.

$$
\text { Dalam Upaya meningkatkan }
$$


kemampuan pasukan perdamaian yang akan dikirim pemerintah Indonesia telah membangun pusat pelatihan yang dinamakan Indonesian Peace and Security Center yang didirikan pada area seluas 261 hektar dikawasan Sentul dan telah diresmikan oleh Presiden SBY pada tahun 2011 lalu. Jika kita menganalisis secara lebih mendalam mengenai upaya-upaya dalam pengiriman pasukan perdamaian tersebut terlihat bahwa kebijakan Indonesia ke luar berkenaan dengan Kemanusiaan ini sangatlah disusun dengan road map yang jelas dan berkesinambungan. Selanjutnya penulis akan membahas mengenai upaya-upaya resolusi konflik yang dilakukan oleh Indonesia sebagai salah satu aktivitas dalam Diplomasi Kemanusiaan.

\section{Resolusi Konflik}

Dalam konteks penanganan konflik disuatu negara setidaknya ada tiga kemungkinan politik luar negeri yang dilakukan oleh negara ke tiga yaitu (1) Berpihak pada negara induk (host country); (2) berpihak pada pemberontak (rebels/ belligerents); (3) bersikap netral atau ambivalen (Wardhani, 2007). Pada peranannya dalam penanganan konflik disuatu negara Indonesia selalu berada pada salah satu posisi tersebut. Keberhasilan Indonesia dalam penanganan konflik antara lain terjadi pada saat membantu resolusi konflik antara pemerintah Filipina dengan MNLF (bangsa Moro). Peranan lainnya yaitu Indonesia telah berhasil menjadi juru damai di Kamboja dengan terlaksananya Jakarta Informal Meeting (JIM). Keberhasilan-keberhasilan Indonesia tersebut telah mampu menciptakan perdamaian di Kawasan Asia Tenggara dan tentunya membuat Indonesia menjadi negara yang disegani di kawasan ini. Berikut ini penulis akan menjabarkan kesuksesankesuksesan yang telah diraih oleh Indonesia dalam penanganan konflik di suatu negara.

\section{Penanganan Konflik di Thailand Selatan}

Penanganan konflik di Thailand Selatan bisa dikatakan sebagai salah satu bentuk kesuksesan dari Diplomasi Kemanusiaan Indonesia. Konflik yang telah berlangsung selama lebih dari 100 tahun tersebut merupakan konflik yang terjadi antara pemerintah Thailand dan pemberontak muslim di provinsi-provinsi selatan Thailand yang tersebar di di wilayah Pattani, Yala dan Narathiwat.

Pihak-pihak yang berkonflik telah menyatakan komitmen mereka untuk mengakhiri konflik di Istana Bogor pada hari Minggu tanggal 21 September 2008. Konflik tersebut terjadi karena adanya gerakan menuntut pemisahan diri yang dilakukan oleh penduduk Thailand Selatan yang berjumlah sekitar 4-5 persen. Mereka merupakan penduduk yang berbeda dengan mayoritas penduduk Thailand dalam hal agama dan ras. Tuntutan pemisahan diri dari minoritas muslim keturunan melayu kepada kerajaan Thailand sudah mulai mucul sejak tahun 1900an yang disebabkan oleh sentralisasi kekuasaan yang 
dilakukan oleh pemerintah Thai dan menyebabkan dampak politik yaitu kurangnya partisipasi politik dari masyarakat di Thailand Selatan. Keberhasilan Diplomasi Kemanusiaan Indonesia ini dapat dikatakan terjadi karena dua faktor penting yaitu (1) Inisiatif Proaktif dan (2) Netralitas Posisi (Wardhani, 2008).

\section{Inisiatif Proaktif}

Inisiatif Proaktif ini disebabkan oleh peluang positif yang dilihat oleh Indonesia untuk memainkan peran regionalnya di Asia Tenggara dengan memanfaatkan modal sebagai salah satu negara berpenduduk muslim terbesar. Insiatif untuk berperan aktif dalam konflik Thailand Selatan inipun sudah lama digagas terutama oleh Jusuf Kalla (ketika beliau menjabat sebagai Wakil Presiden di Pemerintahan SBY). Dalam rangka memainkan perannya sebagai mediator konflik tersebut. Kantor Deputi Wakil Presiden RI meminta masukan dari banyak pihak di Indonesia seperti Ilmuwan, NGO dan lain-lain agar nantinya Indonesia dapat berperan secara maksimal.

Dalam penyelesaian konfik di Thailand tersebut tidak dapat dipungkiri para ulama memainkan peranan yang sangat signifikan. Sebelum tercapainya komitmen untuk mengakhiri konflik pada hari minggu di Istana Bogor tersebut para ulama dari kedua negara terus menerus mengadakan pertemuan dan pembahasan. Peran Ormas-ormas besar di Indonesia seperti NU dan Muhammadiyah sangat berperan dalam suksesnya Diplomasi Indonesia ini.

\section{Netralitas Posisi}

Posisi Netral yang dimiliki oleh Indonesia berkaitan dengan konflik Thailand Selatan menjadi nilai positif bagi pihak-pihak yang berkonflik. Hal yang berbeda terjadi pada Malaysia yang sudah beberapa kali mengajukan diri sebagai mediator konflik tersebut. Niat Malaysia tersebut berkali-kali disampaikan oleh PM Ahmad Badawi kepada PM Thailand Samak Sundarajev. Hal yang membuat Thailand terlihat enggan jika Malaysia ikut berperan dalam penanganan konflik di Thailand Selatan adalah karena keinginan masyarakat di daerah tersebut yang ingin bergabung dengan Kedah dan Kelantan yang merupakan negara bagian dari Malaysia yang paling dekat dengan Thailand Selatan (Wardhani, 2008).

Kondisi diataslah yang menyebabkan akhirnya Thailand setuju ketika Indonesia menawarkan diri untuk penyelesaian konflik yang terjadi di Thailand Selatan karena dalam pandangan pemerintah Thailand Indonesia tidak memiliki kepentingan apapun dalam konflik di Thailand selatan tersebut dan ini tentunya menjadi suatu kemenangan diplomasi yang meningkatkan citra baik Indonesia di Asia Tenggara.

Keberhasilan Indonesia dalam Resolusi Konflik di suatu negara selain Thailand Selatan juga terjadi di beberapa negara lainnya salah satunya adalah perdamaian di Filipina 
Selatan. Berikut ini adalah deskripsi mengenai peranan Indonesia dalam tercapainya perdamaian di Filipina Selatan.

\section{Penanganan Konflik di Filipina Selatan}

Keterlibatan Indonesia dalam penanganan konflik di Filipina Selatan dimulai ketika Filipina dan Moro National Liberation Front (MNLF) meminta Indonesia secara resmi menjadi mediator pada 1993. Sebenarnya dua pihak yang bertikai ini telah mencapai kata sepakat untuk berdamai dengan bantuan mediasi dari Libya. Libya dibawah pemerintahan Qadafi berhasil mendorong kedua belah pihak untuk menandatangani kesepakatan tripoli pada 23 Desember 1976. Inti dari kesepakatan itu adalah MNLF bersedia menerima otonomi dan tidak ada lagi tuntutan merdeka seperti sebelumnya (Tempo, 2013).

Kesepakatan tersebut ternyata dalam realitanya tidak terimplementasi dengan baik akibatnya bentrokan senjata tetap terjadi. Oleh karena itulah akhirnya Filipina dibawah pemerintahan Fidel Ramos meminta bantuan kepada Indonesia untuk menjadi mediator. Sebagaimana diungkapkan oleh Menteri Luar Negeri Indonesia 2001-2009, Hasan Wirajuda bahwa "Ketika pemerintah Filipina meminta, Kita tidak serta merta menerima. Kita tidak mau hanya diminta oleh satu pihak. Tapi harus semuanya termasuk OKI yang dulu memfasilitasi". Pada saat pertemuan di Cipanas, Jawa Barat, pada 14-16 April 1993 semua pihak memberikan mandat kepada
Indonesia untuk memfasilitasi pertemuan antara MNLF dan Filipina (Tempo, 2013).

Dalam upaya penyelesaian konflik di Filipina Selatan ada tiga tingkatan dalam proses perundingan. Pertama, pertemuan resmi yang diketuai menteri luar negeri saat itu, Ali Alatas. Kedua, tingkat komite gabungan. Ketiga, tingkat komite teknis. Selama proses perundingan 1993 sampai 1996 ada empat kali pertemuan resmi, 10 kali pertemuan komite gabungan dan 77 kali di tingkat komite teknis.

Pertemuan komite gabungan yang pertama diadakan pada Desember 1993 di kota Jolo, Pulau Sulu. Hasilnya kedua pihak sepakat untuk melakukan gencatan senjata dan Indonesia diminta untuk mengirimkan pasukan perdamaian. Indonesia dibawah institusi OKI akhirnya mengirimkan pasukan perdamaian sejumlah 16 orang. Dalam perundingan antara MNLF dan pemerintah Filipina ada dua hal yang dianggap cukup alot pembahasannya. Pertama, soal pembagian sumber daya. Kedua, bergabungnya laskar MNLF ke Angkatan Bersenjata dan Polisi Nasional Filipina. Setelah melalui negosiasi yang panjang akhirnya keduanya menandatangani perjanjian damai pada 2 September 1996 dan menjadi cikal bakal lahirnya Autonomous Region in Muslim Mindanao (ARMM).

Contoh-contoh diatas menunjukkan keberhasilan Indonesia dalam menjalankan diplomasi kemanusiaan dibeberapa negara sekaligus meningkatkan citra Indonesia sebagai negara yang sukses dalam memediasi konflik di beberapa negara. Selanjutnya 
penulis akan membahas mengenai bantuanbantuan dalam penanganan bencana di beberapa negara yang dilakukan oleh Indonesia.

\section{Penanganan Bencana}

Dalam penanganan bencana dibeberapa negara Indonesia juga memiliki peranan yang sangat signifikan diantaranya adalah bantuan Indonesia untuk penanganan bencana di negara -negara ASEAN yang dilaksanakan oleh Kementerian Koordinator Bidang Kesejahteraan Rakyat (Menko Kesra) bersama dengan Badan Nasional Penanggulangan Bencana (BNPB) pada tahun 2011 yang menyiapkan dana bantuan sebesar US\$ 3,1 Juta untuk negara ASEAN yang terkena bencana alam seperti Thailand, Filipina, Laos, Kamboja, Myanmar dan Vietnam. Bantuan itu sendiri diberikan dalam bentuk cek yang diberikan ke masing-masing negara dalam nominal yang berbeda-beda. Dimana Thailand mendapatkan US\$1 Juta, Vietnam US\$50 Ribu, Kamboja, Laos, Myanmar dan Filipina masing-masing mendapatkan US\$400 Ribu (Berita8, 2013).

\section{Menteri Koordinator Bidang} Kesejahteraan Rakyat (Menko Kesra), Agung Laksono mengatakan: "Bantuan yang bernilai sekitar Rp28 Miliar tersebut diberikan sebagai bentuk solidaritas kesetiakawanan sosial antar negara ASEAN," dalam konferensi pers di Kantor Kementerian Koordinator Bidang Kesejahteraan Rakyat (Kemenko Kesra). Bantuan sendiri sengaja diberikan dalam bentuk cek karena menurut Menko Kesra itu akan menjadi lebih praktis dibandingkan dengan memberikan bantuan lainnya karena yang mengalami bencana lebih mengerti apa yang mereka butuhkan (Berita8, 2013).

Apabila melihat ke tahun-tahun sebelumnya Indonesia juga berperan aktif dalam penanganan bencana di salah satu negara ASEAN yang sering terkena Bencana yaitu Myanmar. Bencana yang menimpa Myanmar seperti badai nargis yang terjadi pada tanggal 3 Mei 2008 mengakibatkan kerusakan dan jatuhnya korban jiwa dalam jumlah yang sangat besar. Korban yang jatuh jumlahnya sekitar 34.200 jiwa sehingga menimbulkan keprihatinan yang mendalam bagi banyak negara termasuk Indonesia sebagai negara yang sama-sama berada dikawasan Asia Tenggara. Berkaitan dengan hal itulah maka pemerintah Indonesia pada tanggal 8 Mei 2008 pukul 15.00 WIB memberangkatkan tim untuk membawa bantuan dari bandara Lanud Halim Perdana Kusuma dengan menggunakan pesawat Hercules. Tim yang membawa bantuan ini sendiri dilepas oleh Menteri Sosial didampingi oleh Kepala Badan Nasional Penanggulangan Bencana (BNPB) dan Dubes Myanmar untuk Indonesia (DEPKES, 2013).

Tim yang dikirim itu sendiri dipimpin oleh DR. Asep Karsidi, MSc, Deputi Bidang Kerawanan Sosial Kemenko Kesra. Bantuan yang dibawa berupa pakaian 27 koli, biskuit 150 koli, MP ASI 744 koli, obat-obatan 292 
koli, makanan siap saji 4000 koli, selimut 10.000 potong, sarung 5000 potong dan tenda 10 buah, serta bantuan uang tunai sebesar 1 juta US Dollar. Bantuan tersebut tiba di Bandara Internasional Yangon Myanmar pada pukul 13.30 WIB dan diterima langsung oleh Direktur Jenderal Fire Service Department, Department of Social Welfare, Uni Myanmar disaksikan oleh KUAI KBRI di Myanmar. Pada saat itu juga, bantuan tersebut dibongkar dari Hercules TNI AU dan langsung diterbangkan menggunakan helikopter (DEPKES, 2013).

Tiga Aktivitas sebagaimana penjabaran penulis diatas menunjukkan begitu concernnya Indonesia dalam melakukan pencitraan sebagai negara yang menjunjung aspek kemanusiaan. Namun, hal yang berbeda terjadi dalam penanganan masalah kemanusiaan didalam negeri. Berikut ini akan penulis sajikan penjabaran mengenai pelanggaran kemanusiaan yang terjadi di Indonesia yang penulis bagi dalam tiga fokus utama yaitu kebebasan beragama, reformasi peradilan militer yang tidak komprehensif dan kekerasan terhadap perempuan (Papua).

\section{Kebebasan Beragama}

Dalam UUD 1945 sebenarnya secara konstitusional telah memberikan kebebasan kepada setiap warga negara untuk memeluk agama dan kepercayaan dan menjalankan ibadah sesuai agama dan kepercayaan masingmasing. Berbagai produk kebijakan turunan dari UUD 1945 pun sebenarnya juga telah menegaskan jaminan tersebut. Sebagaimana yang tertuang dalam UU No. 12/2005 tentang Ratifikasi Kovenan Sipil dan Politik yang salah satu pasalnya memuat mengenai jaminan kebebasan beragama/berkeyakinan yang juga menjadi landasan bahwa produk hukum internasional tersebut telah menjadi bagian hukum Indonesia yang mengharuskan negara untuk menjaminnya (SETARA Institute, 2009: iii-iv).

Namun kenyataannya dalan penilaian penulis justru walaupun ada jaminan konstitusional dan legal yang dijamin oleh negara melalui UU mengenai kebebasan beragama tersebut tapi pada kenyataannya pelanggaran justru banyak terjadi dan dipicu oleh negara dengan memproduksi UU yang sangat menekan pemeluk agama minoritas. Hal inilah yang akan penulis soroti sebagai salah satu bentuk pelanggaran Kemanusiaan yang dilakukan oleh negara.

Sepanjang tahun 2008 saja telah tercatat 265 peristiwa pelanggaran kebebasan beragama yang tersebar dari bulan JanuariDesember. Peristiwa yang tertinggi terjadi pada bulan Juni (103) peristiwa dan selebihnya tersebar di hampir setiap bulannya (SETARA Institute, 2009: 36). Secara umum peristiwa yang terjadi pada tahun 2008 meningkat secara signifikan dibandingkan dengan peristiwa yang terjadi pada tahun 2007 sejumlah 135 peristiwa pelanggaran kebebasan beragama. Peningkatan ini bisa terjadi karena disebabkan oleh dua hal: 
Pertama, menguatnya penolakan organisasiorganisasi Islam terhadap Ahmadiyah serta mendesak agar pemerintah mengeluarkan keputusan Presiden tentang pembubaran Ahmadiyah dan Kedua, Implikasi serius dari adanya Keputusan Bersama Tiga Menteri, Nomor: 3 Tahun 2008, Nomor: KEP-033/A/ JA/6/2008, Nomor: 199 Tahun 2008 Tentang Peringatan dan Perintah Kepada Penganut, Anggota, dan/ Anggota Pengurus Jemaat Ahmadiyah Indonesia (JAI) dan Warga Masyarakat.

Hal yang paling penting dan dapat dilihat disini adalah SKB dari tiga menteri tersebut menunjukkan begitu mudahnya pemerintah untuk mendiskreditkan suatu agama tertentu dengan berbagai alasan. Hal yang paling signifikan berkenaan dengan Ahmadiyah adalah sebelum SKB tiga menteri dikeluarkan jumlah tindakan anarkis terhadap jama'ah Ahmadiyah ada 193 peristiwa sementara 72 peristiwa lainnya tidak berhubungan dengan Ahmadiyah. Pelanggaran yang berhubungan dengan Ahmadiyah sebelum dan sesudah SKB dikeluarkan cukup besar dari 193 Peristiwa yang berhubungan dengan Ahmadiyah, 48 peristiwa terjadi sebelum adanya SKB dan 145 peristiwa terjadi setelah terbitnya SKB (SETARA Institute, 2009: 39).

Pelanggaran yang terjadi kepada Ahmadiyah dapat dikategorikan sebagai pelanggaran by commission dan by omission yang dalam kerangka hukum Hak Asasi
Manusia merupakan bentuk pelanggaran HAM yang dilakukan oleh negara. Dikarenakan negara sebagai pihak yang terikat baik secara hukum ataupun moral karena telah meratifikasi Kovenan Internasional Hak-hak Sipil dan Politik yang dalam pasal 18 menegaskan tentang kewajiban negara menjamin kebebasan beragama. Secara singkat dapat dikatakan Indonesia telah melakukan kelalaian dengan membiarkan terjadinya pelanggaran Kebebasan beragama. Pelanggaran Kemanusiaan berikutnya yang dilakukan oleh Indonesia adalah berkaitan dengan peradilan militer. Berikut ini adalah penjelasannya.

\section{Peradilan Militer}

Peradilan Militer di Indonesia yang tertuang dalam UU No. 31 Tahun 1997 sebenarnya sejak tahun 2005 telah berupaya untuk direvisi. Hal ini disebabkan karena itu menjadi alat langgengnya kekebalan aparat militer karena memiliki yurisdiksi sendiri untuk mengadili tindak pidana umum. Padahal idealnya mereka harus diadili di pengadilan umum. Hal tersebut menyebabkan berbagai macam kasus pelanggaran Kemanusiaan berat justru diadili di pengadilan militer. Prosesnya tertutup, tidak transparan dan tidak mengakomodir kepentingan korban (KONTRAS, 2009: 3-4).

Kondisi peradilan militer yang seperti itu akan mudah ditebak hasilnya dimana pelaku yang diadili hanyalah pelaku lapangan, hukumannya rendah dan disisi lain kebenaran 
tidak terungkap dan yang paling penting adalah hak-hak para korban tidak terpenuhi. Mulai tahun 2004-2009 upaya untuk merevisi UU tentang peradilan militer ini telah mengemuka di DPR RI namun upaya tersebut seperti menguap dengan sendirinya bahkan DPR tidak mengusulkannya sebagai agenda prioritas dalam Program Legislasi Nasional 2010. Hal ini menunjukkan bahwa ternyata upaya reformasi peradilan militer ternyata tidak didukung kuat oleh pemerintah dan ini sama saja dengan aksi pembiaran terhadap pelanggaran aspek kemanusiaan oleh aparat militer. Berikut ini akan penulis sajikan beberapa kasus pelanggaran Kemanusiaan yang dilakukan oleh aparat militer dan peradilan militer yang dilaksanakan untuk pelanggaran-pelanggaran kemanusiaan tersebut.

Kasus Penculikan dan Penghilangan Paksa Aktivis 1997/1998

Kasus ini terjadi di penghujung pemerintahan Soeharto bersamaan dengan menguatnya desakan reformasi politik di Indonesia. Dua puluh empat orang menjadi korban dalam penculikan tersebut dan baru sembilan orang yang dikembalikan, tiga belas orang masih dinyatakan hilang dan satu orang ditemukan meninggal di Magetan, Jawa Tengah. Duagaan Kuat yang melakukannya adalah Komando Pasukan Khusus (Kopassus).

Pasukan elit dari angkatan darat membentuk unit khusus yang dinamai sebagai
Tim Mawar untuk melaksanakan misinya dengan metode pengambilan paksa. Setelah peristiwa ini terkuak ke publik muncul desakan untuk menuntut pertanggungjawaban keterlibatan ABRI (Angkatan Bersenjata Republik Indonesia). Kemudian, pada 3 Agustus 1998 pemerintah membentuk Dewan Kehormatan Perwira (DKP). Tim ini sendiri diketuai oleh Kepala Staf Angkatan Darat (KSAD) Jenderal TNI Subagyo Hadisiswoyo. Kemudian pada tanggal 6 April 1999 Markas Besar Angkatan Bersenjata Republik Indonesia (MABES ABRI) menggelar peradilan militer untuk 11 orang anggota Tim Mawar yang diduga melakukan penculikan. Sayangnya para terdakwa hanya dituntut dengan kejahatan perampasan kemerdekaan secara bersamasama. Dari 11 anggota Tim Mawar, hanya terdakwa 1 yang ditambah hukuman pemecatan. Sedangkan terdakwa 2-5 hanya ditambah masa tahanan tapi tidak dipecat, selebihnya tidak ada perubahan masa tahanan dan tidak ada pemecatan. Sementara itu, 4 terdakwa lainnya dalam karir kemiliterannya malah mendapatkan promosi kenaikan jenjang karir dalam dinas (KONTRAS, 2009: 64-65).

\section{Kasus Penembakan Mahasiswa Trisakti 1998}

Kasus penembakan ini terjadi pada 12 Mei 1998 dan merupakan puncak dari kekerasan terhadap mahasiswa dalam gelombang aksi mahasiswa yang meluas disemua tempat di Indonesia pada 1997-1998 menuntut agar Soeharto bersedia untuk turun 
dari jabatannya. Disaat yang bersamaan ABRI membentuk PPRM (Pasukan Penindak Rusuh Massa) yang terdiri dari TNI dan Polri.

Pembentukan PPRM tersebut untuk menghalau meluasnya aksi Mahasiswa bahkan panglima ABRI saat itu Jenderal Wiranto menyatakan akan melakukan tindakan tegas (kekerasan) apabila mahasiswa berani keluar kampus dalam melakukan tuntutan reformasi. Kemudian, pada tanggal 12 Mei 1998, pasukan PPRM lah yang pada akhirnya menembaki aksi mahasiswa hingga 4 mahasiswa meninggal dunia yaitu Elang Mulya Lesmana, Hafidin Royan, Hendrawan Sie dan Heri Susanto sedangkan Ratusan Mahasiswa lainnya luka-luka.

Tewasnya beberapa mahasiswa tersebut akhirnya menyebabkan banyaknya desakan agar pemerintah menindak tegas para pelaku penembakan. Akhirnya ABRI memilih membawa para pelaku lapangan (termasuk dari kesatuan polisi) ke pengadilan militer. Akhirnya Pengadilan militer menuntut sembilan terdakwa (dari 11 orang) dari Kepolisian (Brimob) dengan dakwaan pelanggaran hukum pidana pasal 338 dan 351 ayat (3) KUHP (KONTRAS, 2009: 68-69).

Banyak dari Organisasi masyarakat sipil melihat bahwa peradilan militer yang dilakukan oleh ABRI lebih merupakan sandiwara belaka. Terbukti persidangan atas kasus ini meminimalisir kesalahan-kesalahan ABRI secara institusional sekedar menjadi kesalahan aparat di lapangan. Padahal kalau dilihat secara lebih mendalam tindakan represif tersebut tidak bisa dipisahkan dari kebijakan pimpinan ABRI saat itu yang memerintahkan tindakan kekerasan bagi mahasiswa yang melakukan aksi keluar kampus ini merupakan bukti konkret dari bentuk pertanggungjawaban komando. Dalam keputusannya pengadilan hanya menyatakan bahwa petugas dilapangan telah melakukan kesalahan prosedur dan tidak ada upaya dari pengadilan militer untuk mencari dan menunjuk aparat tertentu sebagai penanggungjawab atas kekerasan yang terjadi di trisakti.

Terakhir penulis akan menyajikan satu bentuk pelanggaran Kemanusiaan yang dilakukan oleh negara berkaitan dengan kekerasan terhadap perempuan terutama yang terjadi di Papua. berikut penjelasannya.

\section{Kekerasan Terhadap Perempuan Papua}

Kekerasan terhadap perempuan di Papua tidak dapat dilepaskan dari sejarah panjang konflik di Papua, sejak tahun 1963 walaupun pemerintahan di Indonesia telah mengalami beberapa kali pergantian rezim namun kelihatannya pemerintah Indonesia masih menganggap keamanan di Papua belum kondusif. Hal ini terlihat dari kuatnya pendekatan keamanan teritorial di Papua yang diberlakukan oleh pemerintah. Pendekatan keamanan teritorial pada akhirnya cenderung berdampak negatif terhadap penduduk sipil, termasuk perempuan dan anak. Terutama perempuan Papua yang telah mengalami berbagai bentuk kekerasan berbasis jender 
(KOMNAS PEREMPUAN, 2009: iii-iv).

Dalam tulisan ini penulis akan menyoroti beberapa bentuk kekerasan yang dilakukan oleh negara terhadap perempuan Papua diantaranya adalah kekerasan oleh negara Periode 1963-2009 dan tidak adanya upaya negara untuk memenuhi hak korban atas pemulihan.

Kekerasan Oleh Negara Periode 1963-1998 dan Periode 1999-2009

Papua pada masa ini memang sedang mengalami masa transisi dimulai dari penyerahan wiayah Papua dari UNTEA kepada Indonesia sampai pada periode reformasi. Pada masa rezim Orde Baru sebagaimana di wilayah -wilayah konflik lain di Indonesia, negara menggunakan pendekatan keamanan terhadap kelompok-kelompok sipil yang melakukan perlawanan dan lebih mengutamakan kepentingan pengusaha dan pemerintah pusat tanpa berupaya memahami akar masalahnya. Ini menyebabkan perempuan-perempuan Papua terseret dalam arus konflik dan mengalami berbagai bentuk kekerasan.

Sebagai contoh pada tahun 1965 sebuah upaya perlawanan OPM (Operasi Papua Merdeka) disekitar wilayah Sorong direspon dengan sebuah operasi militer oleh pihak TNI. Tanpa pandang bulu TNI membakar habis rumah orang-orang diwilayah tersebut dan menembaki siapa saja yang dicurigai sebagaimana diceritakan seorang perempuan yang waktu sedang mencari bahan makanan ke hutan dengan bayinya yang berumur delapan bulan bersama dua saudara perempuannya tetapi disana Ia ditembak hingga jatuh pingsan sementara satu saudaranya yang lari membawa bayi ditangkap tentara dan saudara perempuannya yang lain bersembunyi dan dia pergi membawanya ke kampungnya.

Perempuan-perempuan di Papua memang akhirnya menjadi korban yang tidak dapat menghindarkan diri dari kekerasankekerasan oleh TNI dalam menumpas OPM. Dalam rentang waktu 1963-2009 sudah tidak terhitung jumlah korban perempuan yang mengalami tindakan perkosaan, penganiayaan dan penculikan oleh militer. Walaupun era reformasi telah menurunkan rezim Orde Baru dan menghasilkan otonomi khusus di Papua ternyata pendekatan keamanan tetap menjadi ciri utama yang dipakai pemerintah untuk menghadapi ketidakpuasan masyarakat. Peristiwa-peristiwa kekerasanpun tetap mengemuka seperti kasus-kasus yang menurut kesimpulan KOMNAS HAM mengindikasikan kejahatan terhadap kemanusiaan seperti kasus Abepura, Wasior dan lain-lain. Perilaku oknum aparat keamanan yang bertindak sewenangwenang terhadap orang-orang yang dianggap separatis ternyata berimpas pula pada berbagai bentuk kekerasan terhadap perempuan termasuk didalamnya kekerasan seksual (KOMNAS PEREMPUAN, 2009: 21-25).

Kealfaan Negara untuk memenuhi Hak Korban Atas Pemulihan

Hal yang menjadi pertanyaan besar 
menurut penulis disini adalah tidak adanya upaya untuk membantu dari negara terhadap korban-korban tersebut kecuali upaya yang sangat terbatas dari masyarakat sipil dan korban sendiri. Berbagai kasus kekerasan berdampak secara fisik. Misalnya, ada korban yang ditembak sehingga kakinya perlu diamputasi; ada korban yang lidahnya terpotong karena tertembus peluru; ada yang mengalami berbagai masalah kesehatan karena upaya pengguguran kandungan secara paksa; seorang korban perkosaan dan perbudakan seksual selama bertahun-tahun akhirnya meninggal akibat penyakit kelamin yang tidak pernah diobati; Ada korban yang memberikan kesaksian bagaimana anggota keluarganya yang mati akibat kelaparan ataupun terkena peluru ketika mengungsi selama berbulanbulan dan bertahun-tahun di hutan akibat operasi militer. Namun, kesakitan korban tidak cuma fisik, tetapi juga psikis, yang diakibatkan oleh diskriminasi dan pengucilan. Dari berbagai cerita korban diketahui bagaimana seorang korban kekerasan negara dikucilkan masyarakat umum; ada korban yang mengalami diskriminasi sehingga kariernya sebagai pegawai negeri tidak bisa menanjak, atau anaknya tidak diterima disekolah tertentu (KOMNAS PEREMPUAN, 2009: 42).

Hal inilah yang menjadi kealfaan negara dalam mengupayakan upaya pemulihan para korban kekerasan oleh negara. Kenapa tidak ada pengakuan bahwa ada kekerasan yang dilakukan terhadap permpuan sekaligus menghukum para pelakunya. Ini masih menjadi Pekerjaan Rumah bagi Indonesia yang menunggu untuk secepat mungkin diselesaikan.

\section{Penutup}

Dari Pembahasan diatas penulis dapat melihat adanya disparitas yang cukup tinggi dalam konteks isu kemanusiaan di Indonesia. Kebijakan Indonesia ke luar sangat concern terhadap penanganan aspek Kemanusiaan di berbagai negara sampai-sampai Indonesia bisa dikatakan melupakan permasalahan yang sama didalan negeri. Memang pada akhirnya kebijakan ke luar Indonesia yang concern terhadap aspek Kemanusiaan tersebut membuat Indonesia terpilih menjadi anggota Dewan Hak Asasi Manusia (HAM) PBB periode 2011-2014.

Terpilihnya Indonesia tersebut bisa dikatakan sebagai bentuk kesuksesan dari Diplomasi Kemanusiaan yang secara intensif dilakukan oleh Indonesia. Namun yang menjadi permasalahan disini menurut penulis adalah Indonesia alfa dengan masalah kemanusiaan didalam negeri yang penanganannya bisa dikatakan belum tuntas. Menurut penulis seyogyanya Indonesia sebagai Anggota Dewan HAM PBB juga memulai reformasi dalam penanganan masalah kemanusiaan didalam negeri dan itu semua memang didasari oleh political will dari rezim yang berkuasa. 
M. Syaprin Zahidi 


\section{Daftar Pustaka}

\section{Buku}

KONTRAS, Menerobos Jalan Buntu: Kajian Terhadap Sistem Peradilan Militer di Indonesia, (Jakarta: Kontras, 2009)

Komnas Perempuan, Stop Sudah! Kesaksian Perempuan Papuan Korban Kekerasan dan Pelanggaran HAM 1963-2009, (Jakarta, Komnas Perempuan, 2009)

SETARA Institute, Berpihak dan Bertindak Intoleran, (Jakarta: Publikasi SETARA Institute, 2009)

\section{Artikel dan Koran}

Bantuan Kemanusiaan Untuk Myanmar, di unduh 16 September 2013 pada <http:// penanggulangankrisis.depkes.go.id/article/view/6/279/BANTUAN-KEMANUSIAANUNTUK-MYANMAR.htm>

Indonesia Termasuk Paling Aktif Menjaga Perdamaian Dunia, di unduh 14 September 2013 pada $<$ http://nasional.kompas.com/read/2012/05/17/05155750/

Indonesia.Termasuk.Paling.Aktif.Menjaga.Perdamaian.Dunia>

Indonesia Bantu Korban Bencana Negara ASEAN, di unduh 15 September 2013 pada <http:// www.berita8.com/news.php?cat $=2 \& i d=49281>$

Jejak Indonesia dalam Perdamaian Filipina Selatan, di unduh 15 September 2013 pada <http://dunia.tempo.co/read/ news/2013/09/23/118515866/jejak-indonesia-dalam-perdamaian-filipina-selatan.html $>$

Mendorong Peran Aktif Pemerintah Indonesia dalam Pelanggaran HAM Berat di Korea Utara, di unduh 13 September 2013 pada <http://www.kontras.org/index.php\%3Fhal\% 3Dsiaran_pers\%26id\%3D1686>

Misi Perdamaian, TNI Kirim 120 Personel dan 3 Heli MI-17 ke Sudan, di unduh 14 September 2013 pada < http://news.detik.com/read/2013/04/27/151703/2232039/10/misi-perdamaiantni-kirim-120-personel-dan-3-heli-mi-17-ke-sudan>

Wardhani, Baiq L.S.W., "Mengukur Probabilitas Keterlibatan Indonesia dalam Resolusi Konflik di Thailand Selatan", Makalah pada pada diskusi terbatas yang diselenggarakan oleh Biro Hubungan Internasional, Kedeputian Politik, Sekreratariat Wakil Presiden RI bekerjasama dengan Jurusan Ilmu Hubungan Internasional, FISIP Universitas Airlangga, Surabaya pada tanggal 12 Juli 2007.

Wardhani, Baiq L.S.W., Jawa Pos, "Thailand Selatan, Sukses Diplomasi Indonesia", 24 September 2008. 